DOI:

http://e-journal.stit-islamic-village.ac.id/index.php/JECIES

\title{
THE DEVELOPMENT OF FINE MOTOR AND VISUAL MOTOR SKILLS OF CHILDREN 4-5 YEARS OLD TO GET READY WRITE
}

\author{
Neneng Alawiyah \\ Sekolah Tinggi Ilmu Tarbiyah Islamic Village Tangerang \\ Email: nenengalawiyah.stit@gmail.com \\ Naila Attamim \\ Sekolah Tinggi Teknik Cendekia Abditama \\ Email: naila.atamimi@gmail.com
}

Received: 26 Februari, 2020.

Accepted: 05 Maret, 2020.

Published: 30 Maret, 2020

\begin{abstract}
The objective of this research is to describe: (1) the process development of fine motor and visual motor skills of children 4-5 years old, (2) the learning media applied development of fine motor and visual motor skills, (3) the learning method applied development of fine motor and visual motor skills of children 4-5 years old, (4) the learning evaluative applied development of fine motor and visual motor skills of children 4-5 years old to get ready write. The research is implemented at TK A "Plus" Insan Sejati, Cibinong West Java. This study is naturalistic qualitative deskriptive. The process of the research follows the Spradley's advance stages which consists of collecting data by applying observation, interview, and documentation. Data analysis consists of domain analysis, taxonomi analysis, component analysis, and theme analysis. The result of the study show that: (1) the learning activities on the development fine motor and visual motor skills to get ready write are carried out by defference activities applied in each learning process, (2) learning strategy applied by the theacher are: defferent method, media and evaluation.
\end{abstract}

Keywords: Early childhood, Development motor skills, Visual motor skills.

\begin{abstract}
ABSTRAK
Tujuan penelitian ini adalah untuk (1) memahami proses perkembangan keterampilan motorik halus dan visual motorik usia 4-5 tahun, (2) menemukan media yang digunakan dalam pengembangan keterampilan motoirk halus dan visual motorik dalam menyiapkan menulis, (3) mengetabui aplikasi metode yang digunakan dalam upaya pengembangan keterampilan motorik. halus dan visual motorik usia 4-5 tahun, dan (4) penggunaan evaluasi dalam mengembangkan keterampilan motorik halus dan visual motorik usia 4-5 atabun dalam menyiiapkan menulis. Penelitian ini di laksanakan di TK A "Plus" Insan Sejati Cibinong dengan menggunakan metode deskriptif kualitatif naturalistik. Proses penelitian ini mengikuti alur maju bertahap dari Spradley, proses pengumpulan data meliputi: analisis domain, analisis taksonomi, analisis komponen, dan
\end{abstract}


analisis tema. Hasil penelitian menunjuk.kan bahwa: (1) pembelajaran dalam pengembangan keterampilan motorik halus dan visual motorik dalam menyiapkan menulis dilakukan melalui kegiatan-kegiatan yang beragam yang dilakukan pada setiap proses pembelajaran, (2) strategi pembelajaran yang digunakan meliputi: metode yang bervariasi, media yang disesuaikan dengan jenis kegiatan, dan evaluasi yang dilakukan pada setiap akhir kegiatan

Kata Kunci: Anak Usia Dini, Perkembangan keterampilan motorik, Keterampilan visual motorik.

\section{PENDAHULUAN}

Kemampuan membaca dan menulis merupakan dua kemampuan yang sangat erat sekali hubungannya. Menulis merupakan salah satu alat dari komunikasi non verbal dengan orang lain, melalui simbol-simbol goresan tangan seseorang dapat menyampaikan pesannya kepada oarang lain. Kegiatan membaca dan menulis perlu dikenalkan sejak dini dengan cara yang benar dengan tujuan agar ketika memasuki fase berikutnya anak sudah siap untuk kegiatan tersebut diajarkan kepadanya. Akan tetapi perlu diingat jika pengajaran menulis dan membaca yang diberikan salah maka akan berakibat fatal bagi perkembangan belajar anak selanjutnya. Untuk itu perlu adanya kerja sama yang baik antara orang tua dan guru dalam menggali kemampuan tersebut.

Anak Usia 4-5 tahun mengalami perkembangan yang pesat, proses tumbuh kembang kemampuan motorik anak berhubungan dengan kemampuan gerak anak. Perkembangan motorik erat kaitannya dengan perkembangan pusat motorik di otak. Keterampilan motorik berkembang sejalan dengan kematangan saraf dan otot. Oleh sebab itu sesederhana apapun gerakan yang dilakukan anak merupakan hasil interaksi sistem tubuh yang dikontrol otak. Perkembangan motorik halus/koordinasi mata dan tangan berjalan seiring dengan bertambahnya usia dan stimulasi yang diberikan orang orang tua atau guru kepada anaknya.

Menulis adalah salah satu cara anak belajar, agar anak mampu meraih cita-citanya untuk menghantarkannya menuju gerbang keberhasilan yang gemilang. Menulis merupakan kegiatan yang menarik dan menyenangkan, anak-anak sering menggunakan coretan untuk mengeksplorasikan dirinya, baik melalui goresan, gambar, warna dan bentuk. Atau sebagai penuangan keinginan, ide dan perasaannya, karena melalui tulisan seseorang dapat menyampaikan pesan yang tidak bisa disampaikan oleh kata-kata lisan kepada orang lain. Terdapat perbedaan pendapat antara orangtua dan guru. Para orangtua ingin ingin anaknya diajarkan baca dan menulis, dengan alasan agar lulus test masuk sekolah dasar (SD) karena pihak sekolah dasar (SD) akan meyeleksi murid-murid yang sudah bisa baca dan tulis,oleh karena itu guru TK dituntut untuk mengajarkan baca dan tulis kepada anak pada usia 4-5 tahun.

JECIES: Journal of Early Childhood Islamic Education Study Vol. 01, Nomor 01, Januari - Juni 2020 
Idealnya sebelum menulis diajarkan, guru perlu memahami bahwa untuk menulis dibutuhkan kematangan syaraf dan menyiapkan kerja otot. Hal ini diungkapkan oleh Klein, untuk menulis dibutuhkan keseimbangan tubuh seperti kekuatan otot-otot pada batang tubuh, are pinggul dan juga pada otototot tangan dan jari (Marsha, 1990). Selain memperhatikan perkembangan anak, guru juga perlu memberi latihan yang banyak menggunakan gerak seluruh tubuh yang banyak, seperti senam, menari, berjalan, memanjat dan sebagainya. Sedangkan untuk melatih otot halus, guru menyiapkan latihan seperti meremas, mengaduk, menggunting, mewarnai, menggambar, berfantasi dan sebaginya. Menurut Semiawan latihan berfantasi menggerakkan tangan seolah-olah sedang menulis di udara penting untuk dilakukan dalam artian untuk menggambarkan huruf pada anak sebelum anak-anak menuliskan huruf secara nyata di buku atau papan tulis, guna merangsang dan melatih konsentrasi anak agar anak benar-benar siap untuk menulis tanpa terpaksa, kegiatan itu dilakukan sebagai usaha mengembangkan keterampilan menulis (Semiawan, 2008).

\section{METODE PENELITIAN}

Metode yang digunakan dalam penelitian ini adalah metode kualitatif deskriprtif pendekatan Spradley dengan peneliti sebagi instrumen utama. Metode kualitatif digunakan mengingat penelitian ini bertujuan untuk menemukan sesuatu yang baru khususnya yang berkaitan dengan pengembangan keterampilan motorik halus dan visual motorik anak TK dalam kesiapan menulis. oleh sebab itu kebutuhan utama dalam penelitian ini adalah menemukan fakta-fakta empiris secara langsung dilapangan.

Prosedur pengumpulan data penelitian diawali dengan menjalin hubungan dengan pihak Yayasan, kepala sekolah TK dan guru. Dalam proses tersebut peneliti memperkenalkan diri dan mengkomunikasikan maksud serta tujuan pelaksanaan kegiatan penelitian untuk memperoleh izin mengadakan penelitian di TK tersebut. Dari pertemuan tersebut peneliti memperoleh izin untuk melakukan penelitian di TK "Plus" Insan Sejati yang diketuai oleh Dra. Tri Susilowati sebagi kepala sekolah TK "Plus" Insan Sejati. Untuk memperoleh data dan analisis maka tehnik pengumpulan data dilakukan dengan tiga cara yaitu pengamatan, wawancara dan dokumentasi.

\section{HASIL DAN PEMBAHASAN}

\section{A. Kerangka Teoritis}

\section{Keterampilan Motorik Halus}

Cronbach mendefinisikan keterampilan sebagai berikut: keterampilan dapat diuraikan dengan kata seperti otomatik, cepat,dan akurat. Menurut pendapat diatas bahwa keterampilan merupakan hasil dari kerja oto-otot yang

JECIES: Journal of Early Childhood Islamic Education Study Vol. 01, Nomor 01, Januari - Juni 2020 
terlatih secara otomatik, cepat dan akurat. Latihan yang diberikan secara berkesinambungan dan berulang-ulang.

Motorik adalah respon dan gerak. Menurut Kephart keterampilan motorik adalah kegiatan yang bertujuan menampilkan suatu perbuatan khas atau menyelesaikan suatu tujuan tertentu, seperti melemparkan bola. Contohnya menulis, menggambar dan memegang sesuatu. Dalam perkembangan motorik halus anak taman kanak-kanak ditekankan pada koordinasi jari-jari tangan, berkaitan dengan kegiatan memegang, menggunting, menempel, semuanya menggunakan jari-jari yang disebut juga motorik halus, di usia 4-5 tahun koordinasi gerakan motorik halus berkembang pesat, anak telah mampu mengkoordinasikan mata-tangan dan tubuh secara bersamaan (Martini Jamaris, 2003). Perkembangan motorik halus menyangkut hal-hal yang berhubungan dengan jari-jari tangan berkembang pesat pada usia 4-5 tahun. Jika guru atau orang tua ingin melatih pra menulis pada anak inilah saat yang tepat untuk mengenalkannya pada tulisan, karna saat ini anak-anak sudah mulai bisa mengontrol mata-tangannya secara bersamaan.

Dari definisi diatas dapat disimpulkan bahwa yang disebut dengan motorik halus dan visual motorik adalah kecakapan mengontrol otot-otot kecil pada tubuh atau kecakapan mengkoordinasikan mata-tangan secara bersamaan. Dalam pengembangan keterampilan motorik halus ada beberapa hal yang perlu diperhatikan antara lain usia, latar belakang keluarga, budaya, gender, penggunaan alat yang tepat serta bimbingan orang dewasa agar pengembangan keterampilan motorik halus.

\section{a. Perkembangan Penggunaan Tangan}

Ada dua kriteria yang dapat digunakan untuk menentukan penggunaan tangan: pertama seseorang lebih menyukai menggunakan tangan yang satu dibandingkan dengan tangan yang lain. Kedua, kecakapan atau keterampilan yang digunakan sesorang dengan tangan satu dibandingkan dengan tangan yang lain. Studi tentang bagaimana perkembangan penggunaan tangan menunjukkan bahwa dalam beberapa bulan pertama kehidupannya, bayi terampil menggunakan kedua tangannya. Adapun perubahan dari tangan kanan ke tangan kiri bergantung pada posisi seseorang atau benda yang hendak dijangkaunya. Pada usia $2^{1 / 2}-3^{1 / 2}$ tahun, terdapat perubahan yang menonjol ke arah bilateral yakni menggunakan kedua tangan dengan keterampilan dan keseringan yang kira-kira sama. Pada usia 4 sampai 5 tahun, pilihan pada satu tangan menonjol dan perubahan pengunaan tangan yang satu ke tangan yang lain relative tidak sering(B. Hurlock.1978).

b. Langkah-langkah Melatih Motrik Halus 
1) Latihan jari, meluruskan jari dan menggunakan papan merupakan cara yang mudah dan efektif, hal ini bisa digunakan setiap hari untuk masa yang pendek dalam meningkatkan keterampilan.

2) Ajarkan pada anak-anak aspek-aspek apa saja dalam gerak untuk berkonsentrasi sebelum mengikuti latihan.

3) Ciptakan musik untuk lingkungan kerja yang menyenangkan.

4) Guru memiliki tujuan untuk menciptakan kelas pada pelajaran motorik halus, atau untuk menggabungkan gerak dalam memperkaya program, untuk kelompok-kelompok kecil dibutuhkan pendamping bagi anak.

5) Berbagai aktivitas bisa membuat tantangan lebih dengan menggunakan waktu dan jumlah tantangan. Hal ini harus dilakukan ketika anak-anak berhasil melengkapi dan mengoreksi tugas mereka dengan baik.

6) Sediakan buku tugas ini adalah waktu yang dibutuhkan tetapi....ketika anak dan tutor mengetahui dengan pasti apa yang mereka telah lakukan itu bisa menjadi keberhasilan mereka (Burridge and Landy).

c. Lima Prinsip Perkembangan Keterampilan Gerak

1) Prinsip 1: Anak mengembangkan keterampilan motoriknya dalam batok kepala (cephalo-caudal) secara langsung. Anak-anak belajar mengontrol kepala dan bahu sebelum berjalan atau sebelum motorik halus mereka siap.

2) Prinsip 2: Mengontrol gerak dilakukan secara langsung dalam proximal-to-distal. Anak-anak belajar meraih, dan mengontrol bahu sebelum mencapai sikut, pergelangan tangan, dan control jari.

3) Prinsip 3: Keseimbangan harus disiapkan sebelum pergerakan tubuh memungkinkan. Bayi dapat mengontrol bahu sampai atas perut mereka, dan menggerakkan tubuh mereka ke samping kiri dan kanan, depan belakang. Lebih lanjut control adalah menyaring setiap gerak tubuh anak.

4) Prinsip 4: Gerakan pertama mereka adalah menggerakkan seluruh tubuh. Anak-anak belajar untuk tidak menghubungkan gerakangerakan pada satu bagian khusus pada tubuh. Pertama anak meraih dengan kedua tangannya, kaki, mata dan terkadang dengan mulutnya. Kemudian terjadi peningkatan mereka belajar memisahkan gerakan-gerakan mereka dengan satu tangan, satu kaki, sementara tangan yang lain dapat meraih dengan efektif. 
Dalam menggenggam pertama semua tangan dan jari-jari digunakan secara bersamaan. Dan pada perkembangan berikutnya anak sudah dapat menggerakkan jari-jari secara terpisah.

5) Prinsip 5: Anak harus dilatih berkonsentrasi/memperhatikan pada dirinya dan lingkungan agar dapat menghadapi masalah. Berikan kegiatan untuk melatih keseimbangan tubuh. Karena jika anak kehilangan keseimbangan mereka akan meninggalkan semua perhatian mereka dan tugas motorik halusnya (Marsha Dunn Klein, M. Ed., O.T.R, 1990).

\section{Keterampilan Menulis}

Menulis merupakan kegiatan tangan atau goresan tangan dalam menuangkan ide, gagasan dan perasaan untuk dikomunikasikan kepada orang lain. Ada banyak teori yang membahas tentang hakekat menulis, dan para ahli menyimpulkan bahwa menulis merupakan salah satu alat berkomunikasi. Tulisan juga merupakan cara penguatan (bukti).

Dapat dikatakan bahwa belajar membaca dan menulis keduanya merupakan alat berkomunikasi yang tidak dapat dipisahkan karena memiliki keterkaitan dengan kecakapan berbicara dan semua itu merupakan pembelajaran dalam mengembangkan kecakapan bahasa. Bahasa merupakan penyampai pesan pikiran baik dalam bentuk simbol, isyarat atau tubuh. Keterakaitan membaca dan menulis adalah sebagai penyampai ide-ide, gagasan dan perasaan melalui simbol-simbol yang dapat dipahami oleh or ang lain, oleh sebab itu penting mengajarkan membaca dan menulis sejak dini guna menyampaikan ungkapan/aktualisasi diri seseorang.

a. Sembilan Pra Syarat Untuk Belajar Menulis

1) Perkembangan kesiapan: Pada usia earlies anak masuk pada tahap explorarif sensori, dimana anak menjadikan diri mereka sebagai mainan. Di usia ini anak belajar bagaimana menggerakkan bagianbagian tubuh mereka, memisahkan, meraih, dan menggenggam dan kemampuan mengkoordinasikan visual. Pada tahap ini anak belum siap untuk memegang crayon/pensil. Baru pada tahap selanjutnya anak tertarik untuk belajar bagaimana memainkan mainan, sebab akibat. Mainan sangat menarik bagi anak pada tahap ini. Pada usia yang lebih besar anak-anak memilih permainan konstruktif, ini merupakan masa peralihan. Anak-anak belajar mengisi, membangun, menyusun dan melempar secara bersamaan. Mereka mulai mengerti bentuk, ukuran, dan konsep berteman. Perhatian anak bertambah dan pada saat inilah anak 
sudah siap untuk mengenal pensil/mengajarkan menulis, jika pada tahapan ini anak tidak diberikan aktivitas/latihan maka anak dan guru akan mengalami kesulitan.

2) Keseimbangan: Untuk memulai tugas pra-menulis anak harus duduk sendiri, tangan bebas berinteraksi dengan krayon. Kemampuan pra menulis bergerak secara acak, tanda yang ada di kertas merupakan salinan yang lebih kompleks pada bentuk dan surat, keseimbangan menjadi hal yang perlu diperhatikan.

3) Keseimbangan bahu: Kemampuan mengembangkan dan mnegontrol gerak pada bahu adalah hal penting untuk meraih dan mendukung lengan bawah, pergelangan tangan dan gerakan jari semua itu dibutuhkan untuk menahan pensil dan penggunaannya untuk membuat bentuk yang bermacam-macam.

4) Kontrol lengan bawah: Anak harus merasa nyaman menggerakkan lengan bawah atau telapak ibu jarinya pada posisi netral. Anak tidak hanya memiliki tingkatan pada kebutuhan gerak untuk mencapai gerakan-gerakan, tetapi gerakan harus dilakukan secara halus dan terkontrol.

5) Keseimbangan pergelangan tangan: Anak mungkin harus menahan pergelangan tangannya dalam posisi mengontrol gerak secara bertahap, mereka ke dalam dank e luar pada posisi yang stabil. Pergelangan tangan menyangga tubuh hal ini dibutuhkan untuk control jari yang mana dibutuhkan dalam menulis.

6) Menggenggam: Kecakapan menggenggam alat tulis dengan seluruh tangan dibutuhkan untuk mengembangkan kemampuan menulis secara seksama. Jari kelingking di samping tangan untuk keseimbangan sedangkan ibu jari bergerak secara aktif.

7) Peranan menggunakan dua tangan: Kecakapan menggunakan dua tangan bersamaan dapat memberi keseimbangan dalam menulis. Anak pada usia dua tahun memulai beberapa kecakapan pra menulis, mereka belum memiliki keseimbangan tangan. Ketika ada instruksi menulis kegiatan tersebut memungkinkan anak mengguankan tangan secara bergantian dan hal inilah yang diharapkan, karena anak menjadi lebih matang ketika mereka bisa menunjukkan piliihan tangan.

8) Koordinasi gerakan mata dan tangan: Koordinasi mata tangan bereaksi pada bahu, sikut, pergelangan tangan, lengan bawah dan jari-jari itu semua dibutuhkan dalam menulis. Tugas pra menulis bisa dilakukan tanpa bantuan, tetapi dengan pengalaman sensori lainnya, karena sentuhan bisa menggantikan batas visual. 
9) Pengalaman sensori: Anak belajar memegang macam-macam benda, mereka menyaring gerak pada tangan dan jari-jari mereka dalam memainkan puzzle dan mainanan lainnya. Mereka menarik maianan lalu bermain dengan objek yang besar dan kecil dengan menggunakan kedua tangan bersamaan, menggunakan sendok pada saat makan dan memegang objek yang bermacam-macam dengan bentuk, ukuran, dan tekstur yang berbeda, mereka juga belajar di air dan pasir untuk merasakan benda yang halus dan kasar.

b. Faktor-faktor yang Mempengaruhi Menulis

1) Lingkungan; Lingkungan dapat mempengaruhi anak cara mengenal angka. kurangnya tujuan dalam bermain dan bereksperimen dengan benda-benda grafik akan berakibat pada perkembangan. Tekanan dari guru/orang tua untuk menulis dapat menyebabkan ketegangan yang tidak semestinya.

2) Keterampilan motorik halus; kontrol pada motorik halus merupakan pondasi penting untuk keterampilan menulis. Tanpa keterampilan tersebut maka kecermatan dalam memandu pensil akan sangat berpengaruh pada kesiapan menulis.

3) Visual; kesulitan pada penglihatan akan berpengaruh pada koordinasi mata-tangan yang mana dibutuhkan pada aspek-aspek spasial dan kontrol gerak. Kesulitan pada penglihatan sering berakibat pada beberapa kesulitan belajar.

4) Perseptual/spasial; dalam menulis memiliki beberapa kebutuhan spasial seperti, ukuran, bentuk tata letak. Kelemahan dalam spasial bisa membuat anak sangat kesulitan untuk membuat cetakan yang dapat dibaca.

5) Attitude; kesulitan bersikap baik dan kurang perhatian pada sebuah tanggung jawab untuk satu kegiatan yang dipaksakan merupakan alasan bagi anak-anak yang mengalami kesulitan menulis. Anak-anak harus dilatih memegang tanggung jawab, orang tua dan guru harus mendukungnya.

6) Attention Memory; tanpa perhatian pada tugas, seorang anak tidak akan mengingat dengan baik tentang apa yang harus dilakukannya, usaha untuk belajar akan sia-sia. Anak akan merespon dengan baik jika seorang guru memiliki suatu yang baru dan stimulasi yang berbeda-beda, karena daya konsentrasi mereka pendek.

7) Kematangan syaraf tubuh: sangat dibutuhkan untuk keseimbangan tubuh dalam mengkoordinasikan motorik halus dan visual motorik. Kematangan syaraf dapat menstimulasi kerja otot-otot dalam tubuh. 
8) Emosi; orang dewasa menyadari tingkatan emosi dapat mempengaruhi dramatikal menulis(Landy and Burridge.1999).

Semua faktor tersebut dicakup oleh pengembangan keterampilan motorik halus dan koordinasi visual motorik dalam menyiapkan menulis anak usia 4-5 tahun.

c. Tahapan perkembangan Menulis

1) Tahap 1. Coretan-coretan Acak (random scrabbling); coretan acak seringkali digabungkan seolah-olah krayon tidak pernah lepas dari kertas. Warna-warna coretan dapat dikelompokkan bersama dan menyatu atau terpisah dalam kelompok-kelompok setiap halaman.

2) Tahap 2. Coretan Terarah dimunculkan dalam bentuk garis lurus ke atas atau mendatar yang diulang-ulang.

3) Tahap 3. Garis dan bentuk khusus diulang-ulang, atau menulis garis tiruan. Diwujudkan melalui bentuk, tanda dan garis-garis yang terarah;dapat terlihat mengarah dari sisi kiri ke kanan halaman dengan huruf-huruf yang sebenarnya atau titik-titik sepanjang garis dan dapat juga mengarah dari atas ke bawah halaman kertas.

4) Tahap 4. Latihan huruf-huruf acak atau nama. Huruf-huruf muncul berulang-ulang diwujudkan dari namanya; beberapa dapat diakui dan yang lainnya sebagai symbol. Untuk latihan nama dapat menggunakan huruf besar atau yang lainnya kecil.

5) Tahap 5. Menulis nama, nama dapat ditulis di depan atau sebagai cerminan pikiran, di dalam kotakdengan lata belakang atau bayangan berwarna.

6) Tahap 6. Mencontohkan kata-kata di lingkungan; untuk menulis kata-kata dari lingkungan dilakukan secara acak dan diulang-ulang dalam berbagai ukuran, orintasi dan warna.

7) Tahap 7. Menemukan Ejaan; usaha pertama untuk memeriksa dan mengaja kata-kata dengan menggabungkan huruf yang bermacammacam untuk mewujudkan sebuah kata.

8) Tahap 8. Ejaan umum; usaha-uasaha mandiri untuk memisahkan huruf dan mencatatnya dengan benar menjadi kata lengkap (Susan B Neumen,2000).

Sebelum anak-anak diajarkan menulis sebaiknya guru melatih motorik halusnya dengan beberapa latihan-latihan memegang benda-benda kecil disekelilingnya semat-mata untuk mengembangkan keterampilan motoriik halus dan visual motoriknya. Yaitu dengan kegiatan meronce. Merobek kertas, meremas kertas memainkan jari-jari di atas kertas, memungut benda-benda kecil. Menggunting sekitar pinggiran kertas, menggunting dengan sepenuh 
bukaan gunting, membuka dan menggunting terus menerus sepanjang kertas, menggunting berbagai bentuk, menggunting pada garis tebal dengan terkendali (Susan B Neumen, 2000).

\section{Karakteristik Anak Usia 4-5 Tahun}

Anak-anak tumbuh dan berkembang dengan irama yang berbeda-beda mereka memiliki keunikan masing-masing, semua anak mengalami kemajuan melalui rangkaian tahap perkembangan yang telah diperkirakan. Dalam setiap perkembangannya ada ciri-ciri yang sangat melekat pada setiap potensi dirinya.

Umumnya anak usia 4-5 tahun merasa sudah mampu melakukan pekerjaanya sendiri tanpa pertolongan lagi orang dewasa, Erikson mengkategorikan usia 4-5 tahun ke dalam masa inisiatif vs rasa bersalah kedalam teori psikososialnya. Di usia ini anak berkeinginan untuk melakukan kegiatan-kegiatan baru, baik sendiri maupun bersama teman-teman. Pada usia ini pula anak senang mengikuti perilaku orang dewasa, anak juga mulai memahami peranan menurut jenis kelamin. Penting kiranya untuk membantu anak untuk mengeksplorasikan dirinya agar mereka menjadi anak-anak yang inisiatif, kreatif dan bahagia. Sebaliknya jika orang tua / guru selalu membatasi anak untuk mengeksplorasi dirinya maka yang terjadi anak selalu merasa tidak bisa atau gagal.

a. Perkembangan Kognitif

Pada usia 4-5 tahun anak memasuki masa berpikir intuitif, dimana anak telah menunjukkan aktivitas kogniitif dalam menghadapi berbagai hal di luar dirinya. Aktivitas berpikirnya belum mempunyai sisitem yang terorganisir tetapi anak sudah dapat memahami realitas di lingkungannya dengan menggunakan tanda-tanda dan simbol.

b. Perkembangan Afektif

Anak-anak membutuhkan rasa aman, cinta dan perhatian dari orang lain hal ini berlangsung sejak anak masih dalam kandungan sampai perkembangan selanjutnya, rasa kasih sayang yang di dapat dari orang lain untuk mendatangkan rasa aman tetap dibutuhkan danterus berlanjut

c. Perkembangan Psikomotor

Perkembangan motorik merupakan perubahan perilaku motorik yang merefleksikan interaksi antara kematangan organisme tubuh baik pada urat syaraf, otot yang terkoordinasi dan juga lingkungan individu. Keterampilan koordinasi otot halus biasanya dipergunakan dalam kegiatan belajar dalam ruangan seperti menggunting, menempel, mengulek, mengocok dan sebagainya. Sedangkan keterampilan koordinaasi otot kasar dilakukan di 
luar rungan melalui kegiatan meloncat, berlari, memanjat, melempar dan sebagainya.

\section{Strategi Pembelajaran}

Dalam proses pembelajaran guru perlu mengupayakan dalam memfasilitasi poses pekembangan anak ke arah yang positif dan kondusif melalui kreativiatasnya dengan memvariasikan berbagai strategi dalam kegiatan mengajar. Dengan cara menggabungkan berbagai strategi pembelajaran yang guru berikan maka akan merangsang sensory (indera) anak selalu terlibat dalam pembelajaran. Strategi pembelajaran merupakan suatu prosedur kegiatan yang tersusun secara sistematis dalam mengkomunikasikan materi pelajaran kepada siswa agar dapat tercapai tujuan pembelajaran yan telah di tetapkan, ada empat komponen utama yang dapat disimpulkan yaitu: (1) urutan kegiatan pembelajaran, (2) metode pengajaran, (3) media pengajaran, (4) pengelolaan waktu.

a. Metode pembelajaran

Dalam melaksanakan pembelajaran guru harus memiliki strategi agar anak dapat belajar secara efektif dan efisien dalam mengunakan waktu sesuai dengan tujuan yang diharapkan.

Metode bercakap-cakap atau tanya jawab. Melalui pembelajaran tanya jawab/bercakap-cakap guru dapat mengembangkan bahasa anak, anak dapat memperkaya kosa kata dengan percakapan antara teman dan guru. Selain mengembangkan kemampuan bahasa, dengan metode tanya jawab anak juga dapat menambah wawasan dan pengetahuannya tentang sesuatu yang belum diketahui.

Metode bernyanyi merupakan kegiatan anak dalam melantunkan pesan yang mengandung unsur pendidkan. Pesan-pesan pendiidkan akan lebih mudah diingat anak melalui nyanyian. Seperti saat mengajarkan rukun Iman dan rukun Islam, do'a, tata cara berwudhu.

Metode bercerita merupakan salah satu pemberian pengalaman belajar bagi anak TK dengan menyampaikan suatu cerita atau dongeng yang mengandung unsur pendidikan yang disampaikan secara lisan. Melalui bercerita semua spek pendidikan dapat dikemabngkan. Bercerita dapat disajikan dengan gambar atau tanpa gambar bisa menggunakan boneka.

Metode demonstrasi merupakan salah satu cara menjelaskan sebuah informasi kepada anak atau orang lain mengenai sesuatu atau tugas yang akan diberikan kepadanya melalui peragaan yang dilakukan oleh guru. Guru menunjukkan suatu proses kegiatan, menjelaskan dan mengajarkan 
cara-caranya. Metode demonstrasi memiliki makna penting bagi anak TK, antara lain: (1) mengkomunikasikan gagasan, konsep, prinsip, dan peragaan, (2) membantu mengembangkan kemampuan untuk melakukan segala pekerjaan secara teliti, cermat dan tepat dan (3) membantu mengembangkan kemampuan peniruan dan pengenalan secara tepat.

Metode bermain peran adalah permainan yang dilakukan anak untuk memainkan peran tertentu, dengan menirukan perilaku seseorang. Bermain peran dapat dipergunakan untuk mengembangkan seluruh aspek perkembangan anak. Metode latihan atau penugasan adalah kegiatan yang bertujuan untuk memberikan keterampilan agar anak. Selain itu metode ini juga memberikan kesempatan pada anak untuk menyelesaikan tugas yang didasarkan pada petunjuk langsung dari guru. Masing-masing metode tersebut di atas memiliki kelebihan dan kelemahan, oelh karena itu pada proses pengembangan keterampilan mootrik halus dan visual motorik dalam menyiapkan menulis yang efektif di taman kanak-kanak, guru perlu menggunakan metaode yang bervariasi sesuai dengan karakteristik anak dan tujuan pembelajaran tersebut.

b. Media pembelajaran

Media pembelajran pada prinsipnya berguna untuk memudahkan siswa belajar memahami sesutu yang mungkin sulit atau menyederhanakn sesuatu yang kompleks. Dengan kata lain media pemeblajaran dapat difungsikan sebagai alat bantu untuk mensukseskan kegiatan proses belajar mengajar. Media pembelajaran tidak harus mahal apalagi untuk pembelajaran anak TK media yang dibutuhkan bisa dari barang bekas yang ada di sekeliling kita hanya butuh kreativitas guru dalam memodifikasi media tersebut untuk menciptakan sesuatu yang baru dan berguna.

c. Evaluasi pembelajaran

Evaluasi adalah suatu cara untuk mengetahui tingkat perkembangan atau keberhasilan suatu program yang telah dilaksanakan dalam peride tertentu untuk di nilai oleh evaluator kemudian disimpulkan dan diambil keputusan melalui data-data yang sudah dikumpulkan. Evaluasi bukan sekedar kegiatan suatu aktivitas secara spontan dan insidental, melainkan merupakan kegiatan untuk menilai sesuatu secara terencana, sestematik dan terarah berdasarkan atas tujuan yang jelas. Kegiatan yang terencana tersebut dapat menggunakan instrumen evaluasi dengan tehnik tes dan non tes. Tehnik tes terdiri dari tiga macam yaitu tes diagnostik, formatif dan sumatif.

Tes diagnostik digunakan untuk mengetahui kelemahan-kelemahan siswa sehingga berdasarkan kelemahan tersebut dapat diberikan perlakuan 
yang tepat. Tes formatif digunakan untuk mengetahui sejauh mana siswa telah terbentuk setelah mengikuti suatu program tertentu. Dan tes sumatif dilaksanakan setelah berakhirnya pemberian sekelompok program yang lebih besar (Suharsimi Arikunto, 2002). Adapun tehnik nontes dapat dilakukan dengan beberapa cara diantaranya adalah dengan skala bertingkat, kuesioner, dafatar cocok, wawancara, pengamatan dan riwayat hidup. Skala bertingkat menggambarkan suatu nilai yang berbentuk angka yang disusun secara bertingkat mulai dari yang rendah ke ayang tinggi. Kuesioner atau angket dibuat dalam bentuk daftar pertanyaan yang harus diisi oleh responden. Daftar cocok (check list) pada tempat yang sudah disediakan. Wawancara dilakukan dengan mengajukan pertanyaan sepihak kepada responden. Pengamatan dilakuakn dengan mengamati kegiatan responden baik secara aktif maupun pasif. Adapun riwayat hidup merupakan gambaran keadaan seseorang selama hidupnya (Suharsini Arikunto, 2002).

Berdasarkan pendapat di atas dapat ditarik kesimpulan bahwa evaluasi pembelajaran pengembangan keterampilan motorik halus dan visual motorik dalam kesiapan menulis yang dimaksud dalam penelitian ini adalah suatu proses untuk melihat perkembangan belajar peserta didik setelah mengalami proses belajar selama periode tertentu.

\section{B. Strategi pembelajaran pengembangan keterampilan motorik halus dan visual motorik yang diterapkan di TK "Plus" Insan Sejati}

\section{Metode Penugasan}

Metode penugasan atau latihan selalu digunakan dalam setiap kegiatan yang dilkasanakan di sekolah. Metode ini berguna untuk memberikan pemahan kepada anak untuk mengikuti instruksi dan mengajarkan kepada anak untuk melakukan pekerjaannya secara sistematis. Dengan metode penugasan anak dapat melakukan tugas berdasarkan petunjuk langsung yang telah dipersiapkan oleh guru sehingga anak-anak dapat mengalami secara nyata dan melaksanakan tugas scara tuntas.

Metode ini juga berguna untuk memberikan kepada anak untuk mengembangkan keterampilan diri. Dalam penelitian ini ditemukan bahwa metode penugasan/latihan digunakan untuk kegiatan (1) menebalkan, (2) meronce, (3) mewarnai, (4) menggambar, (5) menempel, (6) meronce (7) membuat kolase, (8) dan menggunting.

Berdasarkan uraian di atas, dapat disimpulkan bahwa apabila dalam kegiatan pembelajaran pengembangan keterampilan motorik halus dan visual motorik dalam menyiapkan menulis, guru menggunakan metode penugasan/latihan secara teratur akan mampu mengembangkan keterampilan

JECIES: Journal of Early Childhood Islamic Education Study

Vol. 01, Nomor 01, Januari - Juni 2020 
yang diharapkan dan sikap hidup mandiripada anak, hal ini sekaligus memotivasi anak untuk bisa melakukan sesuatu dengan sendiri sesuai dengan kapasitasnya sebagai seorang anak usia 4-5 tahun. Pemberian tugas bila dirancang secara tepat dan proporsional akan dapat meningkatkan bagaimana cara belajar yang benar dan bila diberikan secara teratur, berkala dan ajeg dapat memotivasi anak untuk belajar sendiri, berlatih sendiri dan mempelajari kembali sendiri.

\section{Metode demonstrasi}

Metode demonstrasi dilakukan dengan memperlihatkan bagaimana melakukan sesuatu kepada anak atau memperagakannya. Berdasarkan hasil penelitian yang ditemukan bahwa guru memperagakan (1) menulis di udara, (2) melipat bentuk rumah, (3) membuat kolase pada gambar rumah, (4) menempel korek api pada gambar rumah, (5) mengulek, (6) memperagakan gerak dalam lagu, (7) mengocok sabun, (8) mencuci, (9) menebalkan huruf arab dan angka, (10) menggunting garis, (11) dan memasukkan air ke dalam botol.

Metode demonstrasi atau peragaan suatu kegiatan yang dapat mempermudah dalam meberi pemahaman kepada anak melalui contoh nyata yang bisa langsung dipraktekkan. Dimana guru memberi contoh agar si anak dapat menirukan apa yang dilakukan oleh guru. Metode ini memiliki makna penting bagi anak TK, antara lain: (1) membantu mengembangkan kemampuan untuk melakukan segala pekerjaan secara teliti, cermat, dan tepat dan (2) membantu mengembangkan kemampuan peniruan dan pengenalan secara tepat. Contoh dalam pengembangan keterampilan motorik halus dan visual motorik dalam menyiapkan menulis, guru memberikan kegiatan seperti memompa air. Guru memperagakan bagaimana agar air itu dapat keluar dengan alat pemompa, dan juga ketika guru memperagakan menulis di udara, anak-anak memperhatikan dan mengikuti gerakan guru.

Dengan demikian metode demonstrasi dapat disimpulkan sebagai salah satu cara menjelaskan sebuah informasi kepada anak atau orang lain mengenai sesuatu atau tugas yang akan diberikan kepadanya melalui peragaan.

Metode demonstrasi dapat dipergunakan untuk memenuhi dua fungsi. Pertama dapat digunakan untuk memberikan ilustrasi dalam menjelaskan informasi kepad aanak. Bagi anak melihat bagaimana suatu peristiwa itu berlangsung, lebih menarik dan memusatkan perhatian, serta lebih menantang dari pada hanya mendengar penjelasan guru. Kedua metod edemonstrasi dapat membantu meningkatkan daya pikir anak TK terutama daya pikir anak dalam meningkatkan kemampuan mengenal, mengingat, berpikir konvergen, dan berpikir evaluatif. 


\section{Metode praktek langsung}

Dalam hasil temuan di lapangan, terdapat beberapa praktek pengembangan keterampilan motorik halus dan visual motorik dalam menyiapkan menulis yaitu (1) anak memperagakan gerakan-gerakan lagu, (2) anak melipat bentuk rumah/baju, (3) anak memompa air ke dalam gelas, (4) anak memasukkan air ke dalam botol, (5) anak mempraktekkan mencuci serbet dan piring, (6) anak mengocok sabun, (7) anak meronce dengan sedotan/manik-manik, (8) anak membuat kolase pada sebuah gambar rumah, (9) anak mempraktekkan menyentil, (10) anak mempraktekkan mengulek.

Metode praktek langsung atau proyek merupakan salah satu cara pemberian pengalaman kepada anak dengan menyajikan berbagai persoalan sehari-hari yang harus dipecahkan secara berkelompok atau individu. Dalam pelaksanaannya guru bertindak sebagai fasilitator yang harus menyediakan alat dan bahan untuk melaksanakan proyek yang telah direncanakan dalam $\mathrm{SKH} / \mathrm{SKM}$.

\section{Bimbingan}

Bentuk bimbingan yang dilakukan guru di TK "Plus" Insan Sejati berupa bimbingan yang disertai dengan penguatan dan bimbingan yang disertai dengan peringatan. Bimbingan yang disertai dengan penguatan dilakukan dengan cara (1) memuji anak dengan berkata 'bagus sayang', 'wah pintar', 'selamat', dan dengan sikap seperti guru mengacungkan jempol kepada anak dan tos dengan anak, (2) meninggikan intonasi suara ketika meminta anak untuk tertib dan menyelesaikan tugasnya.

Pada proses pembelajaran banyak cara yang digunakan sebagai upaya pengembangan keerampilan motorik halus dan visual motorik anak. Salah satu cara untuk memberikan semangat dan dan memotivasi anak untuk meningkatkan kamampuan anak dalam melakukan aktivitasnya adalah dengan membri bimbingan dalam bentuk penguatan.

\section{Media pembelajaran}

Dalam pengembangan keterampilan motorik halus dan visual motorik, guru menggunakan media sebagai alat penunjang kegiatan. Diantara alat tersebut adalah (1) gunting, kertas origami, lem, dan buku gambar digunakan sebagai alat untuk menggunting dan menempel, (2) lem, kertas origami dan korek api digunakan untuk kegiatan kolase, (3) krayon, buku tugas mewarnai, pensil dan buku gambar digunakan untuk mewarnai dan menggambar, (4) buku tugas menulis, dan pensil digunakan untuk kegiatan menebalkan, (5) ulekan dan daun digunakan sebagai alat untuk kegiatan mengulek, (6) alat pemompa, bak besar, gelas aqua, air pewarna digunakan sebagai alat memompa air, (7) corong, botol aqua, ember besar, dan gelas aqua digunakan untuk 
memasukkan air ke dalam botol, (8) penggilasan, sabun, air dan serbet digunakan untuk mencuci, (9) sedotan, tali, dan manik-manik digunakan untuk kegiatan meronce, (10) selang, benang dan dua bangku digunakan sebagi alat untuk melatih oto-otot jari/menyentil, (11) kartu huruf dan kartu baca digunakan sebagai media untuk melatih membaca, (12) iqra, dan buku fikih digunakan untuk mengajarkan mengaji dan mengajar, (13) papan tulis, spidol,dan penghapus digunakan sebagai alat untuk menulis (guru dan murid), (14) play dough, miniatur mobil-mobilan dan binatang digunakan sebagai alat untuk kegiatan bermain bentuk, (15) pewarna, air, piring, dan koran digunakan untuk kegiatan melukis dengan jari.

\section{Evaluasi pembelajaran}

Evaluasi yang dilakukan guru di TK "Plus" Insan Sejati adalah (1) formatif yang dilakukan setiap hari setelah anak-anak belajar, (2) sumatif yang dilakukan pada tengah dan akhir semester. Sehingga dalam evaluasi hasil belajar, dimaksudkan sebagai suatu proses untuk menentukan nilai keberhasilan belajar peserta didik setelah mengalami proses belajar selama periode tertentu.

Evaluasi bukan sekedara kegiatan suatu aktivitas secara spontan dan insidental, melainkan merupakan kegiatan untuk menilai sesuatu secara terencana, sestematik dan terarah berdasarkan atas tujuan yang jelas. Kegiatan yang terencana tersebut dapat menggunakan instrumen evaluasi dengan tehnik tes dan non tes. Tehnik tes terdiri dari tiga macam yaitu tes diagnostik, formatif dan suamtif. Tes diagnostik digunakan untuk mengetahui kelemahankelemahan siswa sehingga berdasarkan kelemahan tersebut dapat diberikan perlakuan yang tepat. Tes formatif digunakan untuk mengetahui sejauh mana siswa telah terbentuk setelah mengikuti suatu program tertentu. Berdasarkan hasil pembahasan tersebut, diperoleh gambaran bahwa strategi pengembangan keerampilan motorik halus dan visual motorik yang diterapkan di TK "Plus" Insan Sejati adalah: (1) meteode bercakap-cakap/tanya jawab, (2) metode demonstrasi, (3) Metode praktek langsuing, (4) bimbingan dengan penguatan dan peringatan, (5) pembiasaan, (6) media pembelajaran. (7) evaluasi pembelajaran. Dengan demikian guru-guru telah menggunakan berbagai strategi dalam mengembangkan keterampilan motorik halus dan visual motoirk di TK "Plus" Insan Sejati, sebagai upaya mengembangkan keterampilan hidup (life skill) dalam menajalani kehidupan sehari-hari dan siap menghadapi tantangan tantangan di masa depan.

Bertitik tolak dari analisis hasil penelitian maka dirumuskan teori subtantif sebagai berikut "Apabila guru telah melakukan serangkaian proses pembelajaran seperti menggunakan metode pembelajaran dengan melibatkan anak dalam tanya jawab dan percakapan, memperagakan, praktek langsung,

JECIES: Journal of Early Childhood Islamic Education Study Vol. 01, Nomor 01, Januari - Juni 2020 
melakukan bimbingan dengan penguatan dan peringatan, membiasakan, menggunakan media yang bervariasi dan melakukan evaluasi pembelajaran, maka anak akan terbiasa dan terampil menggunakan motorik halus dan visual motorik nya dalam menulis kelak".

\section{KESIMPULAN}

Jenis kegiatan yang dilaksanakn di TK "Plus" Insan Sejati berupa melatih kekuatan otot besar dan kecil; senam, bergoyang/gerak dalam lagu yang di nyanyikan pada saat berbaris, dan memanjat tangga titian, (2) menstimulasi syaraf tangan dan jari; mengocok sabun, mencuci, bermain play dough, mengulek, dan memompa air ke dalam gelas, (3) melatih koordinasi motorik halus dan visual motorik; merobek, meronce, menempel, kolase, melipat, melukis dengan jari, menyentil/menggerakkan benda kecil dengan jari, dan menggunting, (4) melatih menuli awal/pra menulis; mewarnai, menebalkan, menggambar, menulis, dan memasangkan huruf menjadi satu suku kata. Hal tersebut mengidentiikasikan bbahwasanya guru telah mengembangkan keterampilan motorik halus anak dan visualmotorik anak sesuai dengan tahapan perkembangan usia anak. Dalam proses pembeljaran, guru menggunakan berbagai cara dalam mengembangkan keterampilan motorik halus dan visual motorik anak. Salah satuya guru menggunakanmetode pembelajaran dengan melibatkan anak dalam tanya jawab, menggunakan media yang bervariasi maka anak akan tebiasa menggunakan motorik halus.

\section{IMPLIKASI}

Pengembangan keterampilan motorik halus dan visual motorik yang dilaksankan memberikan implikasi dalam mengembangkan menyiapkan menulis bagi anak usia 4-5 tahun. Di samping itu guru juga dapat lebih meningkatkan kemampuan dan motivasinya dalam mempelajari hal-hal baru terkait dengan pengembangan keterampilan motorik halus dan visula motorik dalam menyiapkan menulis anak. Oleh sebab itu, upaya pengembangan keterampilan motorik halus dan visual motorik ini dapat dilakukan dengan beberapa cara diantaranya adalah:

1. Terkait dengan pengembangan keterampilan motorik halus dan visual motorik dalam menyiapkan menulis, tentu seorang guru harus memiliki pengetahuan tentang pekembangan anak dan tahapan mengenai kegiatan-kegitan atau pelatihan sebelum mengajarkan menulis.

2. Sebelum mengajarkan kepada anak terlebih dahulu guru harus membaca buku, merencakan dan mencari bahan untuk membuat media yang digunakan untuk setiap kegiatan yang akan dilaksanakan. 
3. Akan lebih baik jika guru memperbanyak menggunakan strategi yang sesuai dengan tahap pekembangan anak. Seperti metode praktek langsung, dan demonstrasi, karena dengan banyak menggunakan metode ini akan lebih mudah bagi anak menyerap informasi apa yanag akan disampaikan atau diajarkan kepada anak, terlebih pada kegiatan pengembangan keterampilan motorik halus dan visual motorik.

4. Gerak tubuh atau olah raga yang dilaksanakan pada saat berbaris sangat membantu dalam mengembangkan kelenturan, kekuatan dan ketahanan otot-otot motorik anak.

5. Evaluasi yang dilakukan secara terus menerus dalam bentuk deskriptif dapat dilihat dan dijelaskan kepada anak serta orang tua.

6. Perlu kerjasama lebih erat lagi antara guru dan orang tua. Dengan demikian akan tercipta hubungan yang harmonis dalam rangka mendidik anak-anak di sekolah dan di rumah. Apa yang sudah dipelajari di sekolah dapat dipraktekakan anak di rumah dalam pengawasan orang tua. Dan apabila anak mengalami masalah, guru juga cepat mengetahui dan mencari solusinya.

\section{REFERENSI}

Allyn and Bacon. 1996. Observation and Participation In Early Chilhood Setting. tp.

Arifin, Tatang M. 1986. Menyusun Rencana Penelitian. Jakarta: CV Rajawali.

Armstrong, Thomas. 2003. Setiap Anak Cerdas. Jakarta: PT Gramedia Pustaka Utama.

Balitbang PUSKUR-DIKNAS.

Bogdan, Robert C and Steve J. Taylor. 2006. Introduction To Qualitative Research Method. New York: John Willey and Son.

Carrol, Seefeldt and Nita Barbour. 1998. Early Childhood Education Introduction, fourth edition. New Jersey: Merril Of Practice-Hall.

Campbell, Linda and Bruce, Dee Dickinson. 2006. Metode Praktis Pembelajaran Berbasis Multiple Intelegences (penerjemah: Tim Intuisi). Depok: Intuisis Press.

Conny R. Semiawan. 2008. Belajar dan Pembelajaran Prasekolah dan Sekolah Dasar. Jakarta: Indeks.

DEKDIKBUD. Kamus Bahasa Indonesia, edisi kedua.

Dit. PADU dan Dirjen PLSP. 2004. Bahan Pelatiban Tentang Sentra. Jakarta.

Durkin, Dolores. 1997. The Kindergarten Child and Reading. New York: IRA Delaware. 
Emilia, Regio. 1989. Development Appripriote Practice : Development Of Education. Tobin, Davidson and Wu.

F, Smith. 1982. Writing and Writer Heinamann Educational Book. London.

Gallahue, David L. t.t. Understanding Motor Development. Indiana.

Gie, Liang. t.t. Pengantar Dunia Karang Mengarang.

Guba, Egon G and Yvonna S. Lincoln. 1985. Naturalistic Inquiry. Bevery Hills: Sage Publication.

Harrel, Denise Dodd. 1992. How To Manage Your Whole Language Classroom. Hunington Beach: Teacher Material, Inc.

Hafferman, James A.W and E Lincoln. t.t. Writing: Collage hand book.

Hurlock, Elizabeth B. 1978. Perkembangan Anak (alih bahasa: dr. Med.Meitasari Tjandrasa \& Dra. Muslichah Zarkasih). Jakarta: Erlangga.

Jamaris, Martini. 2003. Perkembangan Dan Pengembangan Usia Taman Kanakkanak. Jakarta: PPS UNJ.

Klein, Marsha Dunn. 1990. Pre Writing Skill, t.p.

Landy, Joanne and Keith R. Burridge. 1999. Fine Motor Skill and HandWriting The Center For Applied Research In Education. New York.

Semiawan, Conny R. 1990. Pengenalan dan Pengembangan Bakat Sejak Dini. Bandung: PT. Remaja Rosdakarya.

Susan B Neumen. 2000. Learning to Read and Write: Developmentally Appropriate Practices for Young Children. National Association or the Education of Young Children.

Suharsimi Arikunto. 2002. Dasar-dasar Evaluasi Pendidikan. Jakarta: Bina Aksara.

Tarigan, H.G. 1987. Membaca Sebagai Suatu Keterampilan Berbahasa. Bandung: Angkasa.

Spradley, James P. 1980. Participation Observation. New York: Me Graw-Hill Book Company.

UU Sistem Pendidikan Nasional tahun 2003. Bandung: Citra Umbara.

Yulaelawati, Ella, 2004. Kurikulum dan Pembelajaran; Filosofi Teori dan Aplikasi. Bandung: Pakar Raya. 